\title{
9. SUMMARY OF CASCADIA DRILLING RESULTS
}

\author{
G.K. Westbrook, ${ }^{2}$ B. Carson, ${ }^{3}$ and Shipboard Scientific Party ${ }^{4}$
}

\section{INTRODUCTION}

Leg 146 was directed toward investigation of tectonic dewatering in the accretionary wedge at the Cascadia continental margin. At five sites, two principal thematic objectives were pursued: (1) the mechanisms and geological consequences of diffuse flow and channelled flow within the wedge; and (2) the cause of bottom-simulating seismic reflectors (BSRs) and their relationship to the occurrence of gas hydrate and free gas.

Site 888, located in Cascadia Basin near the northern edge of Nitinat Fan, provides a reference section (with particular importance to porosity, temperature, and pore-water geochemistry) for the other sites located on the accretionary wedge. Diffuse fluid outflow from the wedge and the nature of a well-defined BSR were investigated at Sites 889 and 890 off Vancouver Island. Flow through fault zones was investigated at Sites 891 and 892 off Oregon. Site 891 examined the frontal thrust fault that connects to the master décollement. Site 892 exhibited a BSR displaced toward the surface along a hydrologically active fault in the Pliocene section of the wedge.

A wide range of downhole measurements were successfully completed on Leg 146 to characterize the fluid regime on the Cascadia Margin and complement detailed laboratory analyses. In addition, long-term observatories-instrumented borehole seals (CORKs) were deployed for the first time on a modern accretionary wedge at Sites 889 and 892 .

\section{SITE 888}

Drilling at Site 888 penetrated the top $600 \mathrm{~m}$ of the sedimentary section, which the seismic section from Line 89-04 shows has a total thickness of $2.5 \mathrm{~km}$. The lower $1.5 \mathrm{~km}$ of the section has the appearance of a sequence of distal turbidites. The character of the upper 1 $\mathrm{km}$ shows the proximity of a submarine fan with channels, lateral thickness changes, erosional surfaces, and localized progradation.

\section{Lithostratigraphy}

Unit I (0-175.1 mbsf) is composed of Holocene to upper Pleistocene, interbedded gray to dark greenish gray clayey silts, and gray to dark gray, fine- to medium-grained sands, with some thin beds ( $30-50$ $\mathrm{cm}$ ) containing pebbles, volcaniclastic fragments, and pieces of wood. A transition zone in which the proportion of massive sand gradually increases with depth lies between Units I and II.

Unit II (175.1-457.0 mbsf) comprises upper Pleistocene, thick beds ( $>1 \mathrm{~m}$ ) of massive dark gray, fine- to medium-grained sand with interbeds of clayey silt. The unit is predominantly sandy, and core recovery from it was low. The sands are poorly sorted.

'Westbrook, G.K., Carson, B., Musgrave, R.J., et al., 1994. Proc. ODP, Init. Repts., 146 (Pt. 1): College Station, TX (Ocean Drilling Program).

${ }^{2}$ School of Earth Sciences, University of Birmingham, Birmingham B15 2TT, United Kingdom.

${ }^{3}$ Department of Earth and Environmental Science, Lehigh University, 31 Williams Drive, Bethlehem, PA 18015, U.S.A.

${ }^{4}$ Shipboard Scientific Party is as given in the list of participants preceding the contents.
Unit III (457.0-566.9 mbsf) is made up of upper Pleistocene, dark gray firm clayey silt and silt, finely laminated, with thin interbeds of fine to coarse sand and gravel. The unit may be subdivided into two units: Subunit IIIA (457.0-496.0 mbsf), composed predominantly of silts and showing incipient lithification; and Subunit IIIB (496.0$566.9 \mathrm{mbsf}$ ), composed of clayey silts with sands, though it also contains isolated pebbles of granite, granodiorite, basalt, and quartzite, which may be glacial dropstones.

Within the three lithostratigraphic units, three submarine-fan facies types were recognized that are described as Facies B, C, and D, after the model of Mutti and Ricci Lucchi (1972). Facies C and D, interpreted as being deposited by normal- and low-density turbidity currents, are represented in Unit I, with Facies D predominant. All three facies types occur in Unit II, but the sands of Facies B are the principal type. The facies association of Unit II is the "middle fan sub-association." Lithostratigraphic Unit III comprises facies types C and D, which form an "outer fan sub-association." The turbidities in Unit III are of more distal character than those in Unit I.

The magnetic polarity of the cored interval is normal, except for an interval between 98 and $101 \mathrm{mbsf}$ that may correspond to the Blake Event at about 110,000 yr. Radiolarians of the Botryostrobus aquilonaris Zone $(<450,000 \mathrm{yr})$ were found to a depth of $170 \mathrm{mbsf}$. The dominance of the sinistral Neogloboquadrina pachyderma in a normal polarity interval indicates that the cored section is younger than $600,000 \mathrm{yr}$.

The geothermal gradient has been established as $68^{\circ} \mathrm{C} / \mathrm{km}$, from 11 good measurements of temperature down to 315 mbsf. Thermal conductivities measured in the sediment cores increase in value downward through the uppermost $200 \mathrm{~m}$ to a mean value of $1.23 \mathrm{~W} /(\mathrm{m} \cdot \mathrm{K})$ for the section below that depth. The thermal gradient and conductivities yield a heat flow of about $73 \mathrm{~mW} / \mathrm{m}^{2}$ near the seafloor, which increases through Unit I to reach a value of $84 \mathrm{~mW} / \mathrm{m}^{2}$ through Units II and III. The upward decrease in heat flow is probably a consequence of the absorption of heat by the cool, rapidly deposited sediments.

Measurements of porosity and shear strength indicate that sediments in the cored intervals are underconsolidated. Wireline density and neutron logs show that the minimum porosity of the section lies at $300 \mathrm{mbsf}$. The downward increase in porosity shown by these logs beneath $300 \mathrm{mbsf}$, however, may be an artifact of poor hole conditions, especially in the case of the density $\log$, which requires good contact with the wall of the hole. Porosity measured in core samples decreases with depth below $300 \mathrm{mbsf}$, as does porosity derived from the resistivity $\log$. Sonic velocities also increase with depth below 300 mbsf, indicating decreasing porosity (Fig. 1). The general state of undercompaction indicated by the logs and the measurements of physical properties may be attributed to rapid deposition, especially of the sandy section of Unit II. A good match between the seismic profile and the synthetic seismogram derived from downhole logging enables the profile to be correlated accurately with core and logging data from the site. The porosities derived from measurements at Site 888 match broadly, in the overall shape of their distribution with depth, porosity derived from seismic velocities obtained from the multichannel seismic data of Line 89-04 (T. Yuan, G.D. Spence, and R.D. Hyndman, pers. comm., 1992), using the empirical porosityvelocity relation of Hyndman et al. (1993). 


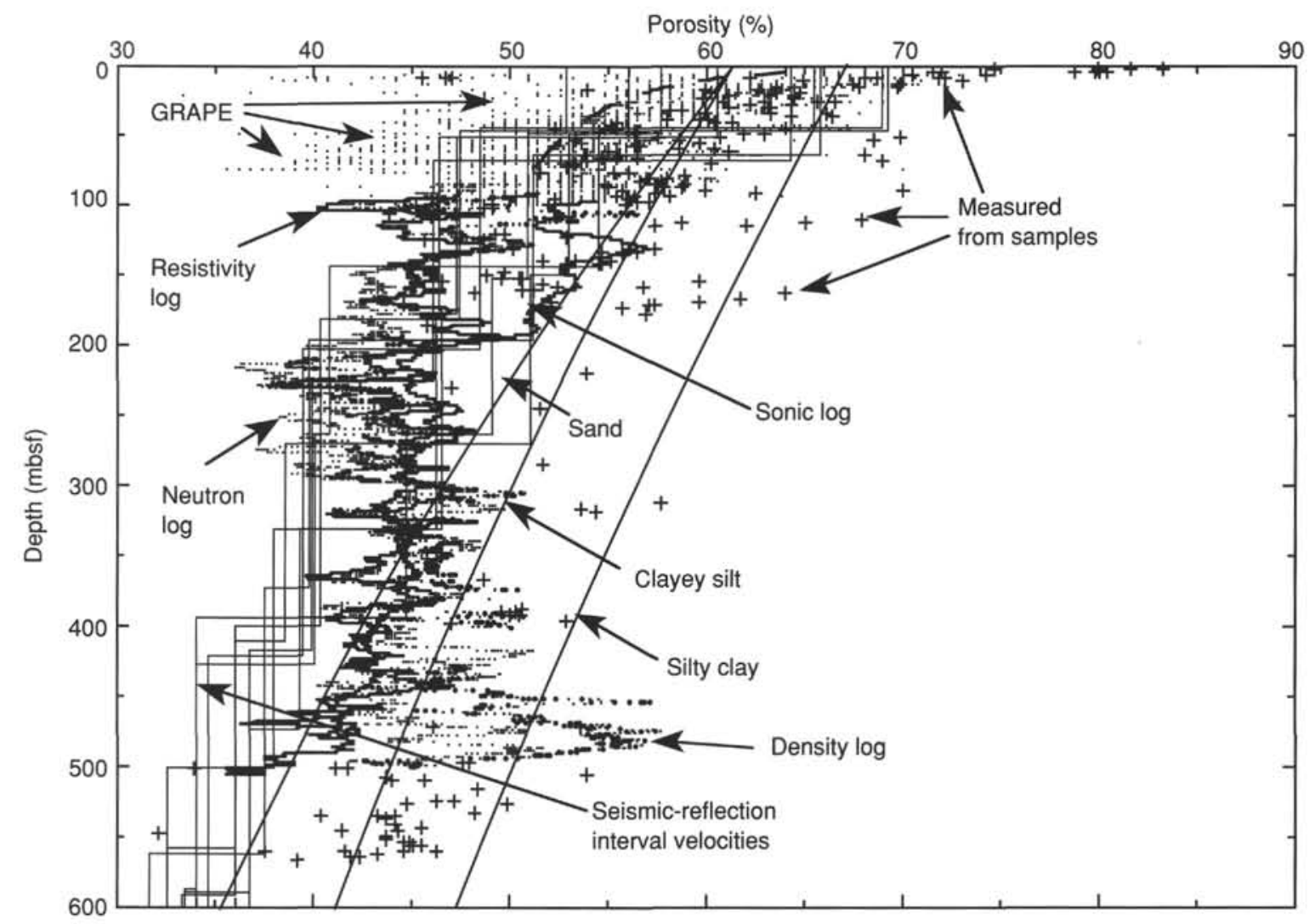

Figure 1. Comparison of porosity as a function of depth, derived from shipboard measurements of physical properties, from geophysical logs down Hole 888B, and from seismic interval velocities obtained from multichannel seismic reflection Line 89-04. Measurements of porosity made on samples with a pycnometer are represented by vertical crosses. Porosity estimated from the GRAPE-determined bulk density, using a grain density of $2.8 \mathrm{Mg} / \mathrm{m}^{3}$, is shown by individual points that plot on vertical lines spaced by the measurement increment. A thick dashed line is the best-fitting logarithmic curve through the GRAPE data. The curves for the porosities derived from the density $\log$, neutron $\log$, resistivity $\log$, sonic $\log$, and seismic reflection data are indicated by labels on the plot. Porosity was derived from the density $\log$, using a grain density of $2.8 \mathrm{Mg} / \mathrm{m}^{3}$. Porosity was derived from the sonic log and seismic reflection data using the empirically derived relation from Hyndman et al. (1992): porosity $=-1.18+8.607 /$ velocity $-17.89 /$ velocity $^{2}+13.94 /$ velocity $^{3}$. Also shown are empirically derived reference curves for normally compacted sand, clayey silt, and silty clay, from Brückmann (1989).

The geochemistry of the pore water in the section varies downward in response to bacterial sulfate reduction, carbonate diagenesis, and fluid flow within some intervals. The variations in several species are, however, quite moderate when compared with the other sites in the accretionary wedge, such as Site 889 . For example, chloride varies from 543 to $571 \mathrm{mM}$ at Site 888 , but at Site 889 chloride varies from 350 to $550 \mathrm{mM}$. Geochemical analysis of pore fluids and gases revealed several interesting aspects of fluid flow, gas migration, and diagenesis in the section. At $70 \mathrm{mbsf}$, chloride concentration sharply decreases by $12 \mathrm{mM}$ from $571 \mathrm{mM}$, to which it had steadily increased from $545 \mathrm{mM}$ at the seafloor. A pronounced minimum in chloride of $18 \mathrm{mM}$ below surrounding values of about $563 \mathrm{mM}$ occurs at 514 mbsf. Flow is required to sustain these anomalies, which would otherwise diminish by diffusion. The anomaly at 514 mbsf lies at a strong seismic reflector that is likely to represent a sand along which pore fluid may have flowed (low core-recovery prevents direct recognition of sand in this interval, and logging was not conducted to this sub-bottom depth).

Overall, organic carbon in the section is at a low concentration $(0.2-0.4 \mathrm{wt} \%)$ and is refractory. Concentrations of methane above $200 \mathrm{mbsf}$ are less than $5 \mathrm{ppmv}$. Ethane, propane, and butane are present only in trace amounts $\left(C_{1} / C_{2}>1000\right)$, indicating that the methane is of bacterial origin. An anomaly of high methane gas content $(68,000 \mathrm{ppmv})$ occurs in a high-porosity sand at $351 \mathrm{mbsf}$. It is not clear that the methane in this sand was formed in situ, yet fluid migration appears to be excluded as an explanation for its presence by the absence of anomalies in the fluid chemistry. In this instance, the gas may have migrated into the sand independently of other fluids.

In summary, investigations at Site 888 revealed that the upper quarter of the sedimentary section on the ocean floor near Vancouver Island comprises a sequence of undercompacted sands and clayey silts that were rapidly deposited in a submarine fan, or in close proximity to it. The rate of sedimentation of the upper $100 \mathrm{~m}$ of section has been close to $100 \mathrm{~cm} / 1000 \mathrm{yr}$, and sedimentation rates in the remainder of the cored interval have at least matched that rate, and were probably greater, judging from the character of sediments in Unit II (middle fan facies). In as many as four intervals of the cored section, evidence is present that fluid flow is occurring. It appears probable that much of this flow arises from differential compaction of heterogeneous sediments within the fan translating to horizontal flow, but the possibility that some of the flow has been transmitted horizontally from a region of compaction induced by the advancing accretionary wedge, $7 \mathrm{~km}$ distant, cannot be excluded.

\section{SITES 889 AND 890}

Sites 889 and 890 are located in water depths of 1326 and 1337 mbsl, respectively. Coring began in bedded, slope-basin sediment, and at Site 889 extended downward into the underlying, deformed sediments of the accretionary wedge. Site 890 was cored to only 50 
mbsf to sample the near-surface sediments. Major objectives at this site were the investigation of a well-developed BSR at $225 \mathrm{mbsf}$ and characterization of diffuse fluid flow from the accretionary wedge. Holes $889 \mathrm{~A}, 889 \mathrm{~B}$, and $889 \mathrm{C}$ penetrated the BSR. A borehole seal (CORK) was emplaced in Hole $889 \mathrm{C}$ to provide long-term observation of the thermal, chemical, and hydrogeological conditions associated with the gas-hydrate zone inferred to overlie the BSR, in a part of the wedge thought to be dewatering diffusely.

Sediments at Sites 889 and 890 range in age from late Quaternary to late Pliocene. A hiatus is present in the record at $87 \mathrm{mbsf}$, separating upper Quaternary from lower Pleistocene deposits. Hole 889A forms the most continuous record, and sub-bottom depths in the following discussion refer to this hole.

\section{Lithostratigraphy-Site 889}

Unit I (0-128 mbsf) includes upper Quaternary clayey silts, fine sands, and diagenetic carbonates comprising slope and slope basin sediments, which are hemipelagites, turbidities, and mass-flow deposits.

Unit II (128-301 mbsf) is compositionally similar to the lower part of Unit I, but it is noticeably more consolidated than the overlying unit and is highly fractured. Diagenetic carbonates are observed throughout the section. Unit II is thought to consist of abyssal-plain silts and clays that have been fractured during accretion. Unit II extends to $300 \mathrm{mbsf}$, beneath which there is a sharp increase in glauconite content, at the top of Unit III. The age is lower Pleistocene to Pliocene.

Unit III (301-345 mbsf): The sediments in Unit III appear to be abyssal-plain deposits like those in Unit II above, but the abundant authigenic glauconite suggests deposition under suboxic conditions. The age is late Pliocene.

\section{Structural Domains}

Domain I (0-104 mbsf) is dominated by subhorizontal bedding, with little apparent deformation of the slope-basin sediments.

Domain II (104-127 mbsf) is characterized by less common sand/silt beds that dip $40^{\circ}-70^{\circ}$ to the west.

Domain III (below $127 \mathrm{mbsf}$ ) is characterized by small-scale fractures that become more common downhole. Below $150 \mathrm{mbsf}$, fractures are pervasive and produce well-developed angular fragments that commonly exhibit an interlocked geometry. The fragment surfaces are sometimes polished and slickensided. The dominant fracture fabric dips $45^{\circ}-60^{\circ}$. Because fractures are ubiquitous in Domain III, and no clear indicators of fault zones were recovered, we infer that tectonic stress in the accretionary-wedge sediments sampled at this site is accommodated largely by distributed strain.

The downhole variation in consolidation is clearly shown in the distribution of bulk density and porosity. Unit I is characterized by normally consolidated deposits in which porosity declines regularly with increasing depth. Between 128 and 160 mbsf (upper Unit II), porosity decreases markedly; the sediments become overconsolidated and remain so to the base of Unit II. Distinct excursions are visible from the general porosity decrease; these correlate with variations in diagenetic carbonate cementation and organic geochemistry (organic carbon content, methane, $\mathrm{N}$, and $\mathrm{S}$ concentrations). The BSR falls within one of these excursions, but it is not uniquely related to porosity, cementation, or organic geochemistry. Lithostratigraphic Unit III exhibits an apparently anomalous increase in porosity with increasing depth.

Two zones were defined from the inorganic chemistry of the pore waters: Zone 1 ranges from 0 to $130 \mathrm{mbsf}$, and Zone 2 is equivalent to lithostratigraphic Unit I, where sulfate declines to zero at $10 \mathrm{mbsf}$ and is accompanied by an increase in alkalinity. The loss of sulfate removes inhibition to carbonate deposition; as a result, $\mathrm{Ca}^{2+}$ and $\mathrm{Mg}^{2+}$ concentrations decrease markedly from 0 to $60 \mathrm{mbsf}$. Chloride concentrations decline from $550 \mathrm{mM}$ at the sediment-water interface to $363 \mathrm{mM}$ at 130 mbsf. The linear change in $\mathrm{Cl}^{-}$is diagnostic of a diffusion gradient within Zone 2 from 130 to $386.5 \mathrm{mbsf}$; $\mathrm{Cl}^{-}$concentrations are nearly constant at $370 \mathrm{mM}$. Concentrations of $\mathrm{Na}^{+}, \mathrm{Mg}^{2+}$, and phosphate are also nearly constant, indicating that the low $\mathrm{Cl}^{-}$ concentration is a dilution effect. Low- $\mathrm{Cl}$ fluids might be derived by lateral advection from land, by dehydration of hydrated mineral species at depths greater than 1-2 km within the accretionary wedge, or perhaps by clay membrane filtration. However, the most probable source of low-Cl fluids is either dissociation of gas hydrate disseminated within this interval during core retrieval or dissociation of the hydrate in situ, following a change in temperature that is sufficiently recent (a few thousand years) for the low chlorinity not to have been dispersed by diffusion or by fluid advection. The degree of dilution suggests that less than $40 \%$ of the pore volume is filled with hydrate. Below 300 mbsf, increases in the concentration gradients of calcium and silica, and a decrease in the potassium gradient, indicate diffusion or mixing with a deeper seated fluid.

Lithostratigraphic Unit I yields elevated methane concentrations $\left(60-80 \pm 10^{3} \mathrm{ppmv}\right)$ below the sulfate reduction zone. Methane declines to $<30 \pm 10^{3} \mathrm{ppmv}$ at the base of Unit I. Over this same interval, ethane and propane are essentially absent and the $C_{1} / C_{2}$ ratio is $>10^{3}$, indicating that the methane is biogenic. A small spike ( $33 \mathrm{ppmv}$ ) in ethane concentration at $129 \mathrm{mbsf}$ (associated with the $\mathrm{Cl}$ minimum) suggests a deeper source for fluids at this level.

Gas compositions vary markedly in the interval from 130 to 247 mbsf. Headspace samples contained $30-77 \times 10^{3}$ ppmv methane, 5-35 ppmv ethane, and 0.5-3.4 ppmv propane. The concentrations of methane found in this interval may come from pore water that is saturated in methane, and some may have been released from dissociated hydrate in cores recovered from the hydrate stability zone. The degree of saturation of methane in the pore water of the cores, however, still remains to be calculated. Below 250 mbsf, the methane concentrations become highly variable. Ethane increases strongly below 300 $\mathrm{mbsf}$, and propane increases below $360 \mathrm{mbsf}$. Within this interval, the $\mathrm{C}_{1} / \mathrm{C}_{2}$ ratio declines from values of about 2000 to $<100$, indicating a mixture of thermogenic and bacterially derived gas.

Holes $889 \mathrm{~A}$ and $889 \mathrm{~B}$ were both logged with the geophysical and Formation MicroScanner (FMS) tool strings; a vertical seismic profile (VSP) was run in Hole 889B. Logs show the base of Unit I to have particularly high porosity. This high-porosity zone is associated with geochemical anomalies $(\mathrm{Cl}, \mathrm{Ca}, \mathrm{Mg}, \mathrm{S}, \mathrm{N}$, methane, ethane), which implies that it collects fluids evolved from greater depths. Within Unit II, high seismic velocity and resistivity values correlate with low neutron porosity, indicating the presence of carbonate cementation.

Six reliable in-situ temperature determinations were made with the WSTP and ADARA tools. Temperature increases linearly with depth, with a gradient of $54^{\circ} / \mathrm{km}$. The data imply conductive heat loss rather than advection, although upward movement of fluid at rates of around $1 \mathrm{~mm} / \mathrm{yr}$ or less cannot be excluded and predict the base of the hydrate stability field for methane and pure water $\left(17^{\circ} \mathrm{C}\right)$ at $260 \mathrm{mbsf}$.

The BSR at Sites 889 and 890 is situated $276 \mathrm{~ms}$ two-way traveltime (TWT) below the seafloor in the migrated seismic section. Time-depth curves derived from the sonic log and VSP indicate that the BSR is located at $225 \mathrm{mbsf}$ in Hole $889 \mathrm{~B}$. Although the sonic log does not exhibit a substantial decrease in velocity across the BSR, the VSP data define a rise in velocity just above the BSR, with a distinct low-velocity zone beneath it (Fig. 2), in which velocities are lower than in seawater. The most probable cause of the low velocities is the presence of small amounts of free gas (Domenico, 1974). The disparity between the sonic log and VSP results may be attributed to flushing the gas phase in the immediate vicinity of the borehole by the circulating seawater during drilling; in addition, the sonic log will not record velocities lower than that of the seawater filling the hole. No evidence exists in either the logs or the cores for the accumulation of hydrate in massive form. However, a temperature of $-1.4^{\circ} \mathrm{C}$ measured in a core from $220 \mathrm{mbsf}$ shortly after recovery on the core-receiving catwalk. This is about $10^{\circ} \mathrm{C}$ lower than temperatures measured in other cores from around this sub-bottom depth and could have been 
Two-way traveltime ( $\mathrm{ms}$ below seafloor)

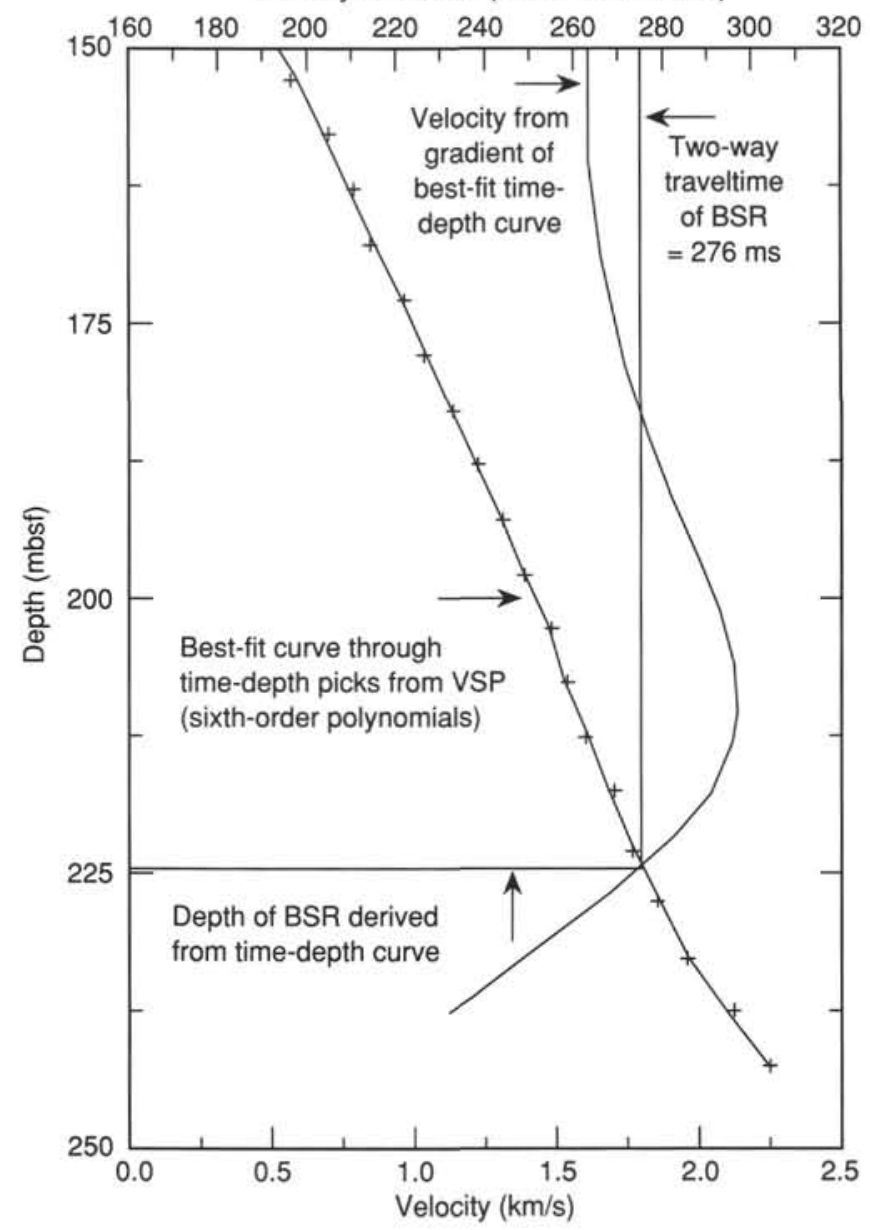

Figure 2. Plot of first arrival times of seismic waves (converted to two-way traveltime below seafloor) vs. depth of the downhole geophone in the VSP at Site 889 . From these data, the reflection time of the BSR below seafloor ( 276 $\mathrm{ms}$ ) is found to correspond to a depth of $225 \mathrm{mbsf}$. By fitting a smooth curve through the time-distance points and differentiating it, the broad variation in velocity in the region of the BSR has been derived. Velocity gently increases to a maximum at about $210 \mathrm{mbsf}$, beneath which it decreases with an increasing steepness to a value of about $1.1 \mathrm{~km} / \mathrm{s}$ at $238 \mathrm{mbsf}$. The velocities lower than $1.5 \mathrm{~km} / \mathrm{s}$ could be caused by the presence of a small quantity of free gas $(<5 \%)$ in the sediment. The increased velocity above the BSR could be produced by the presence of hydrate.

produced by the endothermic dissociation of hydrate filling $8 \%$ or more of the pore space.

At present, the geophysical and geochemical data, taken together, are best explained by the presence of finely disseminated hydrate in the sediment above the BSR at $225 \mathrm{mbsf}$, and by the presence of a small amount of free gas (no more than $5 \%$ ) in the $25-\mathrm{m}$ interval beneath the BSR. If this interpretation of the data is correct, then the experimentally derived stability field for hydrate formed from a solution of pure water and pure methane is not appropriate for the natural system investigated at Site 889 . The estimated stability field for methane and seawater (see Hyndman et al., 1992) gives a closer prediction of the depth of the BSR. The low chlorinity in the interval beneath the BSR might have its origin, at least in part, in dissociation of hydrate accompanying the upward migration of the base of the hydrate stability field, as the upper few hundred meters of the section warmed after the last glacial period.

The pattern of variation in the organic and inorganic geochemistry of the pore fluids and in physical properties at Sites 889 and 890 does not show some of the large discontinuities that are seen at Sites 891 and 892 in association with major faults. With the exception of a narrow interval around $130 \mathrm{mbsf}$, little evidence is present of significant fluid flow that is confined to conduits or fluid pathways provided by permeable beds or faults. Lithostratigraphic Units II and III are pervasively fractured, and it seems probable that flow through the section will be quite dispersed through this fractured rock. Both this and the linearity of the increase of temperature with depth implies that any dispersed flow that is occurring must have a velocity of less than a few millimeters per year.

The borehole seal (CORK) installed in Hole $889 \mathrm{C}$ should provide data on temperature, pressure, and pore-water composition after the effects of drilling have been equilibrated. From these data, it should be possible to determine the temperature profile through the hydrate stability zone in more detail, and post-cruise hydrogeologic tests in this sealed hole should define rates of fluid advection in the accretionary wedge through the region of the BSR.

\section{SITE 891}

Site 891 lies on the westernmost ridge of the Oregon continental margin at $2663 \mathrm{mbsl}$ (Fig. 3). The ridge is an anticlinal thrust sheet formed by movement along the frontal, landward-dipping fault. The fault roots in the décollement beneath the accretionary wedge that forms the outer continental margin. The frontal thrust fault is imaged on seismic reflection Profile OR-5 at a depth of about 375 mbsf at Site 891 (Fig. 4). The negative polarity of that reflector suggested that the region beneath it might contain overpressured fluids. Site 891 was drilled to determine whether fluid advection occurred at this site and, if it did, whether it was focused along the fault zone or through stratigraphic aquifers elsewhere in the section.

Three holes were drilled at Site 891. Only three APC cores were collected in Hole 891A (9.9 mbsf, total depth). Hole 891B provided cores to $472 \mathrm{mbsf}$, although core recovery was very low $(<11 \%)$. Hole $891 \mathrm{C}$ was drilled to $491 \mathrm{mbsf}$ and logged with the quad-combo and geochemical tools and the FMS. Both a VSP and an oblique seismic experiment were also conducted in this hole.

Because of the low core recovery and the compositional and textural similarity of all sediments recovered at Site 891 , only one lithostratigraphic unit was designated; this was divided into three subunits.

Subunit IA (0-198.2 mbsf) displays convolute- and cross-lamination, tilted beds, and convolute deformation. The age is upper Quaternary.

Subunit IB (198.2-383.9 mbsf) shows an increase in induration and fracturing, and a decrease in the degree of sorting. The age is upper Quaternary.

Subunit IC (383.9-472.3 mbsf) returns to less consolidated, less fractured, and better sorted sediments.

The age is upper Quaternary.

The lithologies sampled consist predominantly of clayey silts and fine to medium sand. Allochthonous pebbles and diagenetic carbonate concretions are distributed randomly throughout the section. Several cores below 200 mbsf contain wood fragments. Biostratigraphic and paleomagnetic results are consistent with a post-middle Pleistocene age for the entire column. The structural position, age, and composition of the sediments suggest that Site 891 accumulated as proximal deposits on Astoria Fan before uplift.

Turbidite beds are steeply inclined (about $60^{\circ}$ ) above $84 \mathrm{mbsf}$, overlying variably dipping beds $\left(0^{\circ}-50^{\circ}\right)$ to $198 \mathrm{mbsf}$. Deformation bands appear sparsely in the interval between 100 and 198 mbsf, but no other strain indicators are present above $198 \mathrm{mbsf}$. In contrast, numerous discrete fractures are observed from 198 to $278 \mathrm{mbsf}$ and from 321 to $375 \mathrm{mbsf}$. Two fault zones ( 263 and $375 \mathrm{mbsf}$ ) are recognized within these intervals by the development of shear fabrics and polished and slickensided surfaces. No shear fractures occur between the two fractured zones (278-321 mbsf), but development of a bedding-plane fissility suggests a compaction fabric. Below 375 mbsf, few fractures are observed and bedding dips $14^{\circ}-20^{\circ}$. 


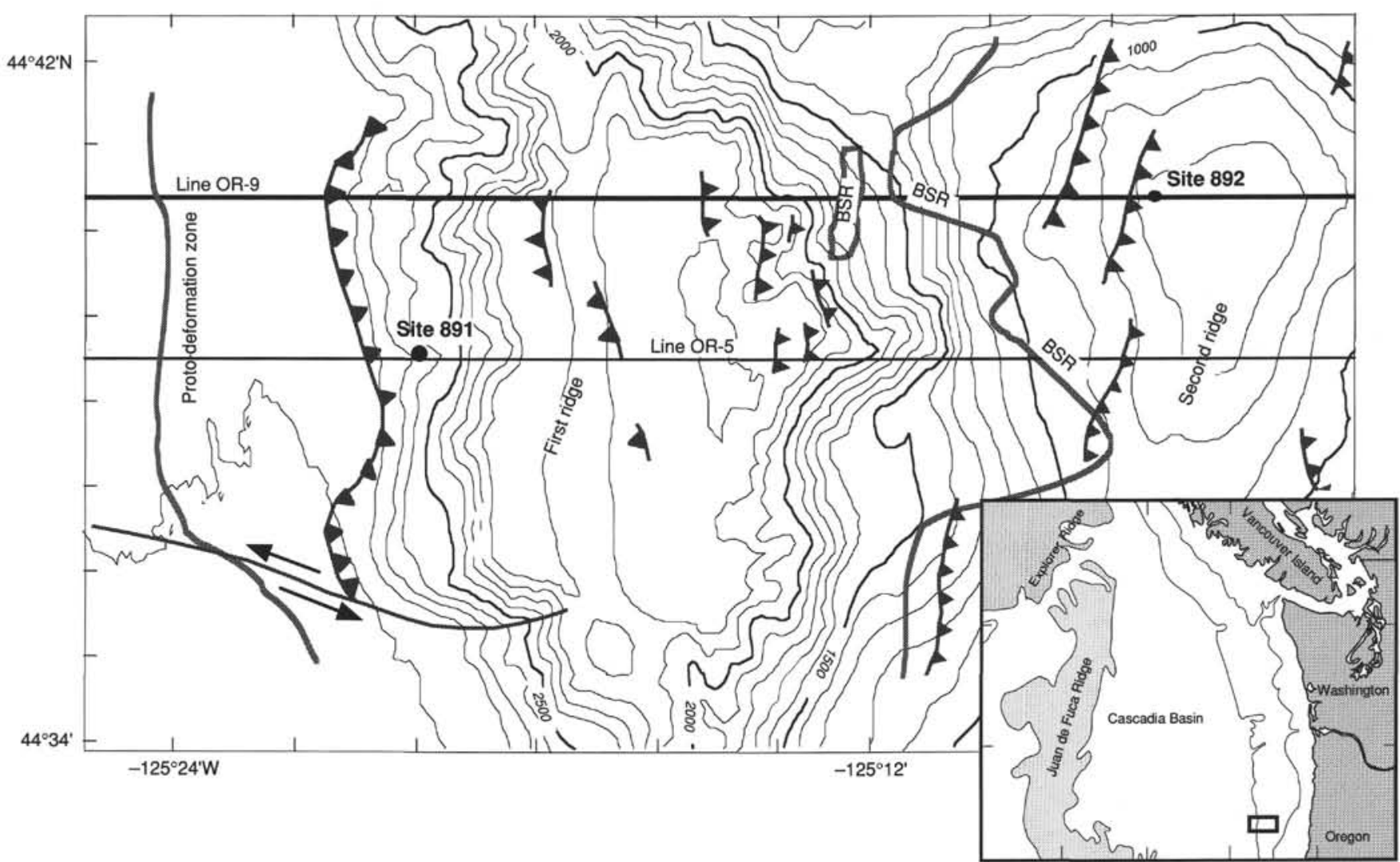

Figure 3. Position of Sites 891 and 892, seismic reflection Lines OR-5 and OR-9, adjacent bathymetry (in meters), and position of thrust faults on the Oregon continental margin.

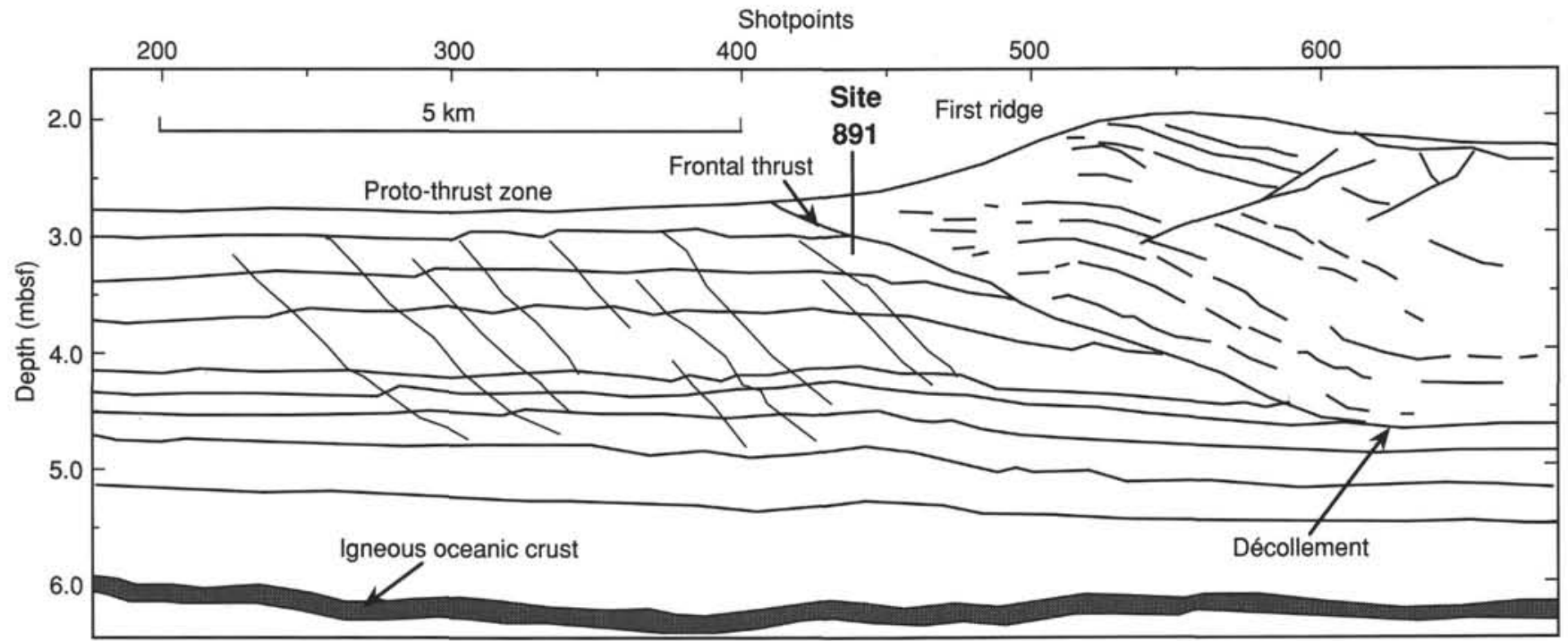

Figure 4. Line drawing of seismic Section OR-5, showing position of Site 891, which penetrates the frontal thrust fault (after R. von Huene, pers. comm.).

Pore-water chemistry and physical properties define three distinct zones in Hole 891B that are not coincident with the lithostratigraphic subunits.

Zone 1 ( $0-200 \mathrm{mbsf})$ is characterized by (1) porosity that declines steadily from about $50 \%$ at the seafloor to about $38 \%$ at depth; (2) low concentrations of methane, carbon dioxide, and a virtual absence of higher hydrocarbons; (3) low $\mathrm{Cl}$ concentration, the presence of sulfate, low alkalinity, and a stable $\mathrm{Mg} / \mathrm{Ca}$ ratio. This zone appears to be a region of normal gravitational compaction that is dominated by sulfate reduction.

Zone 2 (200-440 mbsf) is significantly different from Zone 1 , which suggests little hydraulic communication between the two. Methane concentrations are much higher in Zone 2, and its sympathetic variation with the organic carbon content indicates bacterial 
methanogenesis. Ethane, higher hydrocarbons, and carbon dioxide appear below $240 \mathrm{mbsf}$ and define maxima at $314,340,367$, and 410 mbsf. These maxima represent thermogenic (hydrothermal) hydrocarbon incursions that indicate at least localized fluid advection. The presence of the olefin ethene $\left(\mathrm{C}_{2} \mathrm{H}_{4}\right)$, which is unstable, suggests that the fluid transport system is active. The total nitrogen/organic carbon ratio indicates that organic components have a mixed terrestrial/marine origin. The $\mathrm{Cl}^{-}$concentrations in Zone 2 are high and relatively constant, $\mathrm{SO}_{4}^{2-}$ is absent, and $\mathrm{Mg}$ is low. These concentrations indicate that Zone 2 waters belong to a separate hydrologic system from those in Zone 1, and the interface between the two shows little evidence of diffusion between them. Carbonate cementation at $191 \mathrm{mbsf}$, which is suggested by high velocity $(2.2 \mathrm{~km} / \mathrm{s})$ and resistivity $(2.6$ $\Omega \mathrm{m}$ ) values in the logs, may form a barrier to fluid exchange. Fault zones or intervals of anomalous compaction define several discontinuities (at $260,308,375$, and $440 \mathrm{mbsf}$ ) in the porosity distribution in Zone 2. The two upper zones are apparent in the pore-water $(\mathrm{Li}$, $\mathrm{Mg} / \mathrm{Ca}$ ratio, and silica) and gas $\left(\mathrm{C}_{2}-\mathrm{C}_{6}\right)$ chemistry; the anomalies probably reflect flow along permeable faults or sand beds. The lack of a significant geochemical anomaly at 375 mbsf suggests that the thrust imaged on the seismic reflection profile may be a horizon of little or no active fluid flow.

The zonal boundary of Zone 3 ( $440 \mathrm{mbsf}$ to total depth) is defined primarily on the basis of a pronounced increase in porosity (from $40 \%$ to $60 \%$ ) at 440 mbsf. Fluids beneath this depth exhibit consistently high concentrations of methane and low concentrations of higher hydrocarbons and carbon dioxide. The pore waters are also low in $\mathrm{Cl}^{-}$ and high in $\mathrm{Ca}^{2+}$, suggesting that they have been affected by clay dehydration reactions. The porosity inversion and geochemical signature suggest that the active portion of the frontal thrust may have stepped down to near the top of this interval. Zone 3 appears to represent the footwall section beneath the frontal thrust fault.

The pore-water chemistry in Hole 891A (0-9.9 mbsf) is substantially different from that characterized by seawater or by Zone 1 in Hole 891B. Concentrations of $\mathrm{Cl}^{-}, \mathrm{Si}$, phosphate, $\mathrm{Mg}^{2+}, \mathrm{Na}^{+}$, and $\mathrm{Ca}^{2+}$ are similar to those observed in Zone 2, suggesting a minimum depth of origin of $200 \mathrm{mbsf}$. The disparity in pore-water composition between Holes $891 \mathrm{~A}$ and $891 \mathrm{~B}$, which were separated horizontally by only 30 $\mathrm{m}$, demonstrates significant heterogeneity of fluid flow at this site.

\section{SITE 892}

Site 892 lies on the western flank of the second ridge on the accretionary wedge that underlies the Oregon continental slope $(674 \mathrm{mbsl}$; Fig. 3). The site was positioned to intersect both the BSR (73 mbsf) and a hydrologically active, landward-dipping fault (107-113 mbsf). Site 892 was drilled to delineate the hydrogeology and fluid chemistry of a Pliocene portion of the accretionary wedge, to assess the importance of a fault zone as an active aquifer, to determine the history of flow along this fault and its effect on the temperature regime, to analyze the structures developed around active and relict fault zones, and to investigate the effect of focused fluid advection on the occurrence of gas hydrates and the BSR.

Coring extended to a depth of $176.5 \mathrm{mbsf}$ in Hole 892A. Hole $892 \mathrm{~B}$ was drilled to the same depth; a packer test was conducted in the hole, and a borehole seal (CORK) was deployed to provide longterm observation of the thermal, chemical, and hydrogeological conditions at the fault zone. Hole $892 \mathrm{C}$ was logged to a depth of $125 \mathrm{mbsf}$ with the seismic stratigraphic log, the lithodensity log, and the FMS, and a VSP was run. Holes 892D (0-166.5 mbsf) and 892E (0-62 mbsf) provided cores and temperature determinations additional to those collected at Hole 892A, in selected intervals.

The section cored at Site 892 is divided into three domains on the basis of structural characteristics. Domain I ( $0-52 \mathrm{mbsf})$ consists of moderately dipping $\left(<35^{\circ}\right)$ beds of silt and fine sand, with fractured intervals in some of the silts. A fault zone is inferred at $52 \mathrm{mbsf}$ (Domain I/II boundary) from an abrupt reduction in bedding dip to $10^{\circ}-20^{\circ}$, and by fractures in the FMS log. The presence of shear bands and stratal disruption in the interval $62.5-67$ mbsf suggests a fault zone. Fractured intervals, scaly fabric, and veins increase downhole in Domain II (52-106 mbsf) to culminate in a strongly developed fault-zone fabric in Domain III (106-175 mbsf). The interval between 116 and 147 mbsf exhibits a pervasively sheared, consolidated mélange fabric.

Radiolarian-based biostratigraphy of the Pliocene section confirms the positions of the fault zones. Two stratigraphic inversions are apparent in Hole 892A: between 45 and 50 mbsf and between 107 and $117 \mathrm{mbsf}$. In Hole 892D, the lower inversion occurs between 76 and $110 \mathrm{mbsf}$, and the upper inversion is not recognized. In addition, the biostratigraphy defines a hiatus at 23-30 mbsf in Hole 892A and at 32-43 mbsf in Hole $892 \mathrm{~B}$.

The sediments at Site 892 consist dominantly of terrigenous silty clay and clayey silts with scattered sand layers. The sediments at Site 892 appear to be Pliocene abyssal-plain deposits, similar to the lowermost sediments recovered at DSDPSite 174 in Cascadia Basin. A single lithostratigraphic unit that was divided into two subunits was defined.

Subunit IA (0-67.8 mbsf) is richer in sand than the deeper section of the hole. Most of the sand layers consist of authigenic glaucony pellets. Grain size decreases downward through the subunit, whereas the proportion of biogenic silica increases near its base. The age is lower to upper Pliocene.

Subunit IB (67.8-176.0 mbsf) contains fewer sand layers, less glaucony and biogenic silica, and an irregular distribution of grain sizes. Most distinctively, however, Subunit IB exhibits the fracturing and stratal disruption that define structural Domains II and III. The age is upper Pliocene.

Marked downhole discontinuities occur in physical properties at Site 892 . Abrupt dislocations in the trends of bulk density and porosity occur at 17, 67.8, 116, 144, and 164 mbsf. The discontinuity at 17 mbsf is clearly a function of the gas hydrates observed between 2 and $17 \mathrm{mbsf}$, the sublimation of which disrupted the near-surface sediment, resulting in a very high porosity $(>67 \%)$. Beneath the region in which hydrate was visible in the cores, porosity declines normally to about $55 \%$ at $67.8 \mathrm{mbsf}$ (top of lithostratigraphic Subunit IB), below which this is variable $(42 \%-62 \%)$, with little evidence for further general consolidation. Compaction appears to be enhanced locally about the faulted intervals where strain hardening has occurred. These same intervals are adjacent to porous, fractured zones which, at 67.8 and $116 \mathrm{mbsf}$, apparently serve as active fluid-flow zones.

Active flow at Site 892 is indicated by geochemical anomalies in the pore waters, by a packer test that measured superhydrostatic fluid pressures, and by local higher-temperature excursions from an otherwise linear increase in temperature with depth. Furthermore, the presence of gas hydrates and elevated levels of hydrogen sulfide at 2-17 mbsf may be an indirect consequence of the underlying flow regime.

Bacterial methanogenesis occurs at very shallow depths (possibly within the upper $2 \mathrm{mbsf}$ ) at Site 892 . Although biogenic methane probably persists to the base of the hole, it is mixed with higher hydrocarbon gases below $67.8 \mathrm{mbsf}$. Thermogenic hydrocarbons $\left(\mathrm{C}_{2}-\mathrm{C}_{6}\right)$ were sampled and must be derived from deeper within the prism (1-4 km), as the maturity of the local kerogen is insufficient to produce them. The gases also include ethene, an unstable olefin, the presence of which implies advection of petroliferous pore waters, although gas migration might occur independently. The distribution of higher hydrocarbons suggests movement of fluids through the section at $67.8,107$, and 125 mbsf.

Gas hydrates occur as macroscopic crystals, pellets, and aggregations distributed in the upper $17 \mathrm{~m}$ of sediment, and probably as disseminated deposits to $73 \mathrm{mbsf}$. The disseminated hydrates have a patchy distribution, as indicated by the variable dilution of $\mathrm{Cl}^{-}$. An analysis of temperature measurements in the cores with observable hydrate $(<17 \mathrm{mbsf})$ indicated that less than $10 \%$ of the pore space is filled with hydrate if the endothermic dissociation of hydrate is the cause of cooler than normal temperatures. 
The occurrence of high concentrations of $\mathrm{H}_{2} \mathrm{~S}$ in near-surface sediments and its presence to $60 \mathrm{mbsf}$ indicate either that $\mathrm{H}_{2} \mathrm{~S}$ is formed bacterially but its usual removal as monosulfides and/or pyrite is inhibited, or that $\mathrm{H}_{2} \mathrm{~S}$ is allochthonous to these near-surface sediments and has a hydrothermal source. The close association of $\mathrm{H}_{2} \mathrm{~S}$ with the gas-hydrate zone suggests that free sulfide may be stored as clathrate in situ.

The geophysical logs in Hole $892 \mathrm{C}$ (located $30 \mathrm{~m}$ south of Hole $892 \mathrm{~A}$ ) are sensitive, though somewhat inconsistent, indicators of fault zones inferred from the cores. Between 61 and $68 \mathrm{mbsf}$ and between 83 and 90 mbsf, measurements of high density, high velocity, and high resistivity from the logs define fault zones that are apparently strainhardened. The same intervals show temperature and ethane anomalies, and the upper interval exhibits a pronounced discontinuity in density/porosity. By contrast, a fault zone inferred to occur at 106 mbsf (ethane anomaly, fracturing in core) is represented by low resistivity and bulk density and high neutron porosity.

The time-depth curve derived from the VSP and sonic log place the depth of BSP at 73 mbsf. Below this level sonic velocity drops to a uniform value of $1.5 \mathrm{~km} / \mathrm{s}$, indicative of borehole fluid, which implies that velocity in sediment surrounding the borehole is even lower. The low sonic velocities are attributed to free gas in the formation below the BSR and are confirmed by the VSP $(\leq 1.4 \mathrm{~km} / \mathrm{s}$, $73-91.5 \mathrm{mbsf}$ ). These low velocities could only be provided by the presence of free gas, which must be the principal cause of the BSR.

Spatial and temporal variation in temperature are indicators of advective flow. In-situ temperature measurements at Site 892 define a linear temperature gradient of $51{ }^{\circ} \mathrm{C} / \mathrm{km}$, which suggests that heat transfer is predominantly by conduction. Superimposed on this gradient, however, are two anomalous points at 67.5 and $87.5 \mathrm{mbsf}$, which have temperatures $1.6^{\circ} \mathrm{C}$ and $2.5^{\circ} \mathrm{C}$ higher than predicted by the linear gradient, respectively. These points are attributed to local advection of warm fluids along fault zones delineated by the logs. The limited vertical extent of the anomalies, however, indicates small spatial diffusion of the temperature signal, and requires very recent fluid flow (within the last $10 \mathrm{yr}$ ).

The temperature distribution also constrains the hydrate stability field at Site 892. The temperature gradient predicts the base for the stability field of hydrate formed from pure methane/pure water at 120 \pm 4 mbsf. The BSR, which is commonly interpreted to indicate the base of the hydrate zone, is situated at $73 \mathrm{mbsf}$. The difference between the measured temperature and predicted temperature at the BSR $\left(1.9^{\circ} \mathrm{C}\right)$ suggests that the experimentally derived phase boundary for pure methane/pure water is not directly applicable to the gas-hydrate system on this margin and that a methane-seawater system is more appropriate. The resolution of this question must await determination of the gas composition of the hydrates and may require experimental determination of an appropriate gas/seawater hydrate stability field.

The drill-string packer experiment determined that the pressure of the fluid in the formation at Site 892B is about $0.25-0.50 \mathrm{MPa}$ above hydrostatic. However, because the hole was open for at least 12 hours prior to the test, the apparent formation pressure does not represent an equilibrium condition. A post-cruise record of pressure (and temperature) recovery at Site $892 \mathrm{~B}$ will come from the borehole seal (CORK) deployed in this hole.

\section{SUMMARY}

\section{The principal outcomes of the leg were as follows:}

1. Fault zones in the accretionary wedge were shown to be active conduits for fluid outflow from the wedge or from sediment subducted beneath the wedge. The presence of higher hydrocarbon gases in the fluids sampled from the fault zones favors the latter source, because geothermal gradients within the wedge of around $50^{\circ} \mathrm{C} / \mathrm{km}$ require thermogenic gases to be generated from a depth between 2 and $4 \mathrm{~km}$.
2. It has been demonstrated that one fault zone at least (at Site 892 ) is overpressured, and evidence exists from both the downhole temperature measurements and the pore-fluid geochemistry that transient flows occur in the vicinity of fault zones.

3. The regions between major faults, as exemplified by Site 889 , have fluid pressure that is not significantly greater than hydrostatic, and appear to have lower rates of fluid flow than the fault zones, judging from the linear geothermal gradients. The presence of higher hydrocarbon gases in the fault zones gives some indication of the path lengths of a few kilometers for the transport of fluids along the fault zones. The concentrations of ethane and propane in the lower part of Site 889 are, however, greater than the concentrations in the fault zones at Site 891 at the toe of the wedge off Oregon, although nowhere near as great as those in the fault zone at 892 . It appears that diffuse flow, over the 1-m.y. or so period since accretion of the sediment at Site 889 , has moved fluid from the depth at which thermogenic hydrocarbon gases are generated as much as channelled flow along the fault zone to the frontal thrust have done in the period of less than $300,000 \mathrm{yr}$ since the frontal thrust began to form, although it seems probable the horizontal component of transport is greater at Site 891 . Deeper than $130 \mathrm{mbsf}$ at Site 889 , an unusually low concentration of chloride occurs in the pore water $(370 \mathrm{mM})$. Sympathetic reduction in the concentrations of sodium, magnesium, and phosphate indicate that this is a product of dilution, probably caused by the water released from the dissociated methane hydrate. Above the BSR, the dissociation occurred when the cores were retrieved; however, below the BSR, the dissociation would have been a consequence of the upward migration of the BSR in the past, probably following the last glacial period. If so, the rate of fluid flow through the sediment must have been less than $1 \mathrm{~mm} / \mathrm{yr}$ for the diluted water not to have been substantially flushed from the system.

4. The overall form of the curves of porosity decrease with depth measured at Sites 888 and 889 , off Vancouver Island, is matched well by the variation of porosity with depth predicted from seismic velocities, although absolute values may be in error by a few percent. The accreted sediments at Site 889 are less compacted than sediments in the Cascadia Basin at the same depth below the seafloor.

5. Off both Oregon and Vancouver, the age and type of sediments cored in the two more landward sites, together with structure and stratigraphy shown by seismic reflections, indicate the accretion of a thick section from the incoming sediments of the Cascadia basin is a feature of only the last $1 \mathrm{~m} . \mathrm{y}$. or so. None of the sandy Astoria Fan sediments drilled through at Site 891 were encountered in the late Pliocene section of Site 892 .

6. The detection of seismic velocities of $<1500 \mathrm{~m} / \mathrm{s}$ by vertical seismic profiles and sonic logs at Sites 889 and 892 show that the principal cause of the BSR that underlies most of the Cascadia continental margin is the presence of a small amount of free gas in a zone lying beneath the base of the methane-hydrate stability field.

7. Downhole temperature measurements at Sites 889 and 892 place the temperature at the BSR to be about $2^{\circ} \mathrm{C}$ less than predicted from the stability field for hydrate formed from pure water and methane. It seems that the stability field for methane and saline water is more likely to be appropriate. The consequence of using the BSR to estimate heat flow on the basis that the BSR lies at the base of the pure water methane stability field would be to overestimate heat flow.

8. Heat flow calculated from downhole measurements at all three sites where reliable measurements were made $(888,891$ and 892$)$ is significantly less $(30 \%-40 \%)$ than measurements made close by with heat-flow probes in the seabed. Calibration of the downhole instruments (A. Fisher, pers. comm.) and the heat-flow probes (E. Davis, pers. comm.), and the software used to derive temperatures have been checked thoroughly, and there appears to be little room for instrumental error. Therefore, this difference represents a real effect, which might be a recent change in bottom-water temperatures. This difference in the two data sets is perplexing, because the surface-measured heat-flow data were satisfactorily modeled with thermal models of 
the margins, based on reasonable assumptions of thermal conductivity, sedimentation rate, and age of oceanic lithosphere.

9. The presence at shallow depth (2-17 mbsf) of hydrogen sulfide at high concentrations of up to 19,539 ppmv in cores containing hydrate was unexpected. The high concentration indicates that, at least, some of the hydrogen sulfide was held in clathrate form.

10. Instrumented borehole seals (CORKs) were installed in Holes 889 and 892 in an accretionary wedge for the first time. They offer the opportunity to measure the temperature profiles free from drilling disturbance, and of measuring changes with time in downhole temperature and pressure.

\section{REFERENCES $^{*}$}

Brückmann, W., 1989. Typische Kompakationsmuster mariner Sedimente und ihre Modifikation in einem rezenten Akkretionskeil (Barbados Ridge). Beitr. Geol. Inst. Univ. Tübingen, Rh. A, 5:1-135.

Domenico, S.N., 1974. Effect of undersaturation on seismic reflectivity of sand reservoirs encased in shale. Geophysics, 39:759-769.

Hyndman, R.D., Foucher, J.P., Yamano, M., Fisher, A., Berner, U., Brückmann, W., Byrne, T., Chabernaud, T., Firth, J.V., Gamo, T., Gieskes, J.M.,
Hill, I.A., Karig, D.E., Kastner, M., Kato, Y., Lallemant, S., Lau, R., Maltman, A.J., Moore, G.F., Moran, K., Olafsson, G., Owens, W.H., Pickering, K.T., Siena, F., Taira, A., Taylor, E., Underwood, M.B., Wilkinson, C., and Zhang, J., 1992. Deep sea bottom-simulating-reflectors: calibration of the base of the hydrate stability field as used for heat flow estimates. Earth Planet. Sci. Lett., 109:289-302.

Hyndman, R.D., Moore, G.F., and Moran, K., 1993. Velocity, porosity, and pore-fluid loss from the Nankai subduction zone accretionary prism. In Hill, I.A., Taira, A., Firth, J.V., et al., Proc. ODP, Sci. Results, 131: College Station, TX (Ocean Drilling Program), 211-220.

Mutti, E., and Ricci Lucchi, F., 1972. Le torbiditi dell' Appennino settentrional: introduzione all'analisi di facies. Mem. Soc. Geol. Ital., 11:161-199.

\footnotetext{
Abbreviations for names of organizations and publication titles in ODP reference lists follow the style given in Chemical Abstracts Service Sounce Index (published by American Chemical Society).
}

\section{Ms 146IR-012}

